\title{
Evaluation of Post-Merger Performance on a Value Based Framework: A Case of Hindalco Industries Ltd. and Novelis Inc.
}

\section{Dr. Anjala Kalsie ${ }^{1}$ \\ Dr. Ashima Arora ${ }^{2}$}

Effulgence

Vol. 15 No. 2

July-December, 2017

Rukmini Devi Institute of Advanced Studies

E-mail : effulgence@rdias.ac.in, Website : www.rdias.ac.in http:/ / effulgence.rdias.ac.in/user/default.aspx https://dx.doi.org/10.33601/effulgence.rdias/v15/i2/2017/77-89

\begin{abstract}
Multiple approaches have been used to evaluate the post-merger performance. The objective of the paper is to demonstrate value based approach for evaluating post-merger performance. Enterprise Value Added (EVA) as outlined by Stewart in 1980 has been chosen as the value based measure. EVA methodology was employed as a tool to evaluate the post-merger performance of the combined entity Hindalco in the paper. The merger deal between Hindalco Industries Ltd. and Novelis Inc. carried out in the year 2007 has been chosen to demonstrate Enterprise Value Added (EVA) as outlined by Stewart. The value obtained from the analysis found that the combined entity couldn't produce expected performance. The five years post-merger analysis of combined entity's performance revealed four years of negative economic value (EVA). This underlined that the actual EVA couldn't keep up with the expected EVA improvements in the combined entity, thereby validating the fears of the target company being over-valued during acquisition process by acquiring company, Hindalco.
\end{abstract}

Keywords: post-merger performance, Enterprise Value Added, stock market reaction JEL CODE: G34, C52, G11

\section{INTRODUCTION}

$\mathrm{T}$ wentieth century has seen multiple waves of corporate mergers and acquisitions throughout the world, changing the face of corporate landscape. Cross border mergers and acquisitions (M\&A) have become more frequent in recent times. Cross Border M\&A has increased from $\$ 97.3$ billion in 1987 to $\$ 2400$ billion in 2010 worldwide, as per Thomson Reuters. All this is complicated by the fact that a significant fraction $(40-80 \%)$ of studies of past M\&As have found the results failing. This paradox prompts one to question as to what kind of impact an approach to performance measurement can have on the results.

Multiple approaches have been used to evaluate the post-merger performance. Some of the most common approaches are Share market performance, Accounting Measures, Subjective Assessment of Managers, Expert Assessment, Balance Score Card, Value Based Measures. As per Cording et al (2010), $92 \%$ of studies have used stock market and accounting measures as the approaches to evaluate the performance of mergers.

1. Assistant Professor, Department of Management Studies, University of Delhi, India

2. Assistant Professor, Shaheed Sukhdev College of Business Studies, University of Delhi, India 


\section{Different Performance Measures}

It would be not only difficult but incorrect to present one approach superior to another. It is the purpose and context of study that defines the most appropriate approach. Each approach has its advantages and disadvantages. A brief description of some of the approaches is presented here.

\section{Share Market Studies}

This has been one of the most used approaches in Merger \& Acquisition evaluation. The approach is rooted in the Efficient Market Hypothesis. It measures the movement in share prices with the unanticipated M\&A event. It assumes that share market incorporates this information to give rational, accurate and complete measure of expectations of value creation from the new entity. These studies can be both short and long term. It also assumes that there are no shocks to share market during the event window other than the merger and acquisition.

This approach has several advantages including that approach is based on wide public opinion and thus can be considered rational. The approach incorporates easy data availability and thus significant sample size. Another merit is that the influence of external factors is easy to eliminate in short term studies and also that measurement of abnormal returns enable cross industry comparisons. But there are certain limitations of this approach as well. Some of them are inherent assumptions need not always be true, though data is easily available yet it is difficult to implement, entities not listed cannot be evaluated, study cannot consider all the objectives associated with the M\&A and performance can be evaluated at combined entity level and not on the level of individual units.

\section{Accounting Based Measures}

This approach takes a long-term view of evaluation and monitors the actual performance as depicted in accounting measures such as return on capital
(ROC), return on invested capital (ROIC) and return on employed capital (ROEC) among others. These parameters are compared for multiple periods before and after the acquisition. This approach takes ROC as the ultimate objective of firm and which is reflected in accounting measures. These indicators can be in the domain of growth, profitability, productivity and innovation. This approach has several advantages. Few of them are that it considers returns that have been realized, easily implementable, and can capture the impact of multiple M\&A objectives. But this approach has its limitations. Some of them are results are impacted by the effect of outside factors, focuses on past rather than present expectations of future, accounting data is subject to manipulations, varying accounting standards and GAAPs across countries might lead to inconsistency, comparison is difficult.

\section{Balance Score Card (BSC) Approach}

This approach uses balance score card methodology to evaluate post-merger performance. This approach captures performance across five broad dimensions as listed below

1. Financial Performance

2. Learning \& Growth

3. Customer Satisfaction

4. Internal Business Processes

5. Environment

This approach captures the comprehensive performance but relies on accounting measures to judge performance across five broad categories.

\section{ECONOMIC VALUE ADDED (EVA)}

Economic Value Added (EVA) is an operational performance measure which deviates from conventional profitability measures on essentially two accounts. First, in the overall cost, it takes account of opportunity cost associated with the capital i.e. it is closely related to the concept of residual income. Second, it incorporates multiple corrections to reported revenues to minimize the 
impact of accounting errors. The advocates of EVA preferring it vis-à-vis conventional profitability measures argue that EVA is more strongly related to wealth maximization. A positive value indicates the presence of economic profits and vice versa. EVA is the difference of cost of capital deducted from Net Operating Income after Tax (NOPAT), i.e.,

$$
E V A=N O P A T-c * I
$$

Where, NOPAT is profit after depreciation and taxes but before interest cost, $\mathrm{c}$ is the cost of capital generally taken to be WACC and I is the Invested Capital in the beginning of the year for which the EVA must be calculated. Operations of a company can only be said to create values for shareholders when the return on capital exceeds the cost of capital. EVA is also referred as the Return Spread i.e. the difference between return on capital employed and the cost of capital. EVA can be used as a comprehensive tool of management because it redirects the focus of company operations and managerial direction on creating wealth for the shareholders. EVA can then be used as a tool for capital budgeting, mergers and acquisition decisions, compensation planning, financial reporting and bench marking.

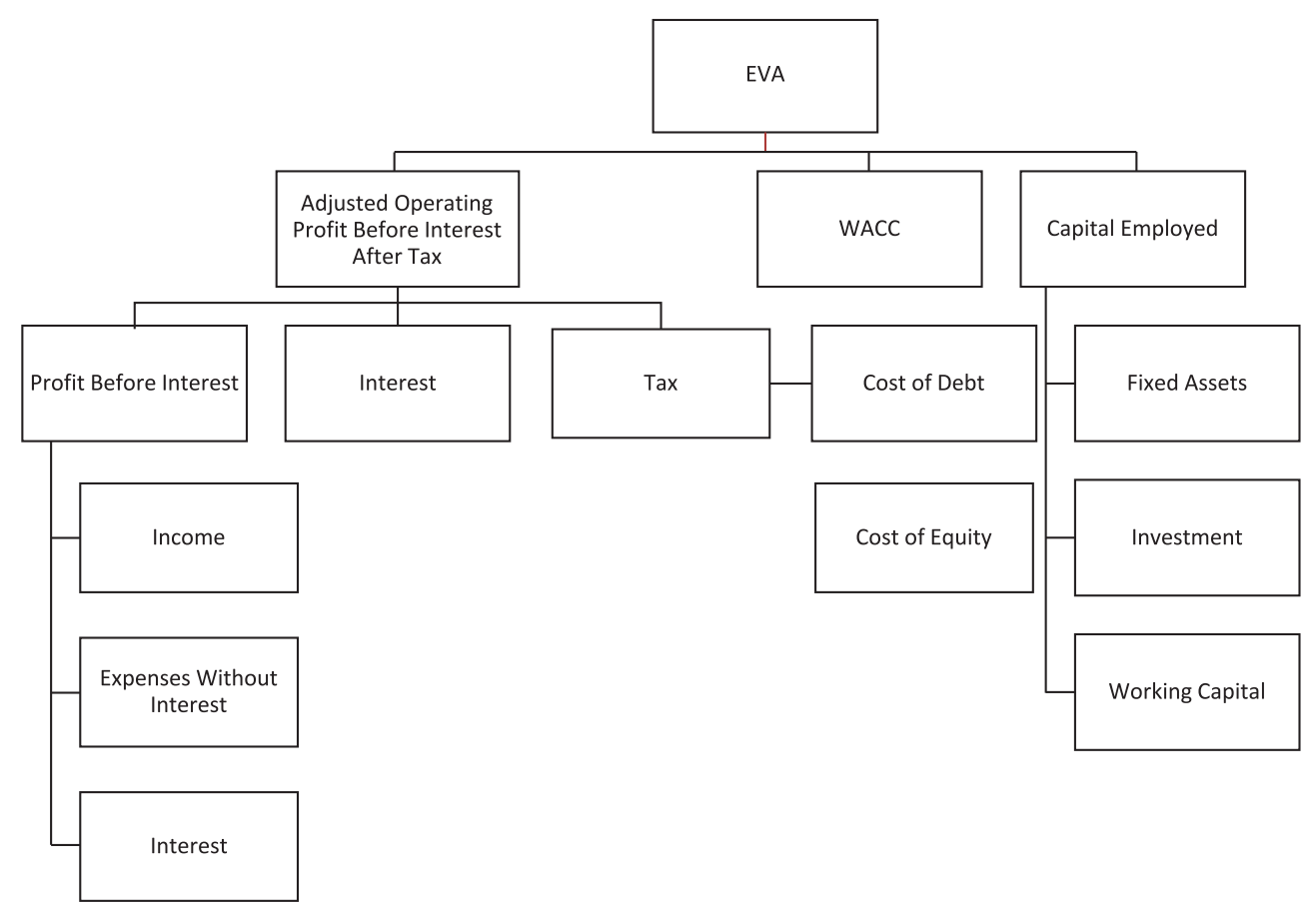

Figure 1: Economic Value Added

\section{Historical Evolution of EVA}

The concept as a theoretical construct has been in existence since 1890. It was Alfred Marshall, British Economist, who defined it as slightly different concept of economic profit. Marshal stated that real meaning of profit for a business is "What remains of his profits after deducting interest on his capital at the current rate may be called his earnings of undertaking or management". It was this definition that set apart the concept of economic profit from the accounting based measures of profitability or wealth creation such as return on equity (ROE), return on investment (ROI), earnings before interest, tax, depreciation and amortization (EBITDA) and net operating income (NOI). It was the work of Irving Fisher and later Nobel Laureates Miller and Modigliani, during 20th century that further developed the concept of economic profit in the context of corporate valuations. 
In the realm of practice, residual income was adopted by General Electric in the decade of 1950s. It was New York based Stewart \& Co. that made several accounting adjustments in the calculation of residual income on the basis of GAAP figures and christened it as EVA. Stewart defined EVA as profit which considers cost of both debt and equity invested in the operations of a firm. Stewart made more than 160 adjustments to the accounting figures for the calculation of EVA.

\section{EVA Compared with Traditional Measures}

Solomon and Laya (1967), Fisher (1986) and Livingston and Solomon (1970) have shown that there is significant difference among true rate of return and accounting rate of return. Hence, they concluded that the later cannot be used as a measure of former. The most common indicator used to measure the performance is return on capital and is also considered a good one. Return on Capital is calculated in different manner by different companies and has been known by different names such as ROCE, ROI and ROIC among others. One major problem with all of them is that it is not necessary that maximizing this rate of return will also maximize wealth creation for the stockholders.

EVA gives similar results as derived from NPV or DCF which are well established as some of the best analytical methods from investors' point of view. Just as IRR might not be a true indicator for project selection, the ROI also need not give the best results for investors. Just as IRR shall be used along with NPV, ROI can as well be used with EVA. Performance measures such as EPS and ROI have certain problems as identified below:

- Possibility of manipulation of income due to inconsistency in the definition of income, investments and assets

- Varying accounting choices create scope for manipulation

- GAAP follows accrual system of accounting and thus to some extent neglects cash flows and time value of money leading to inaccuracies

- Managers might ignore beneficial asset replacement to retain high performance rewards

- Might lead to individual units performing to the detriment of overall organization

\section{EVA Compared with other Value Based Measures}

There exist multiple value based tools to measure the performance of organizations. Some of them are Cash Flow Return on Investment (CFROI), Cash Value Added (CVA), Shareholder Value Added (SVA), Adjusted Economic Value Added (AEVA) and Refined Economic Value Added (REVA). CFROI developed jointly by BCG and HOLT Value Associates, compares gross cash flows (GCF) with gross investments (GI) both adjusted for inflation. The ratio of GCF and GI is then translated into an IRR by taking account of limited useful life of depreciating assets and residual value of nondepreciating ones like land.

CVA is calculated as the difference of Operating Cash Flow (OCF) and Operating Cash Flow Demand (OCFD). OCFD is a measure of average annual cost of capital. AEVA and REVA are modified versions of EVA. While AEVA takes current value of assets as opposed to book value, REVA uses market value of the firm in the beginning of period instead of book value. Some of these measures are dependent upon cash flows and thus might be more reliable but at the same time their calculation is not very simple and they tend to rely on subjective data.

\section{Calculation of EVA}

AS already stated the EVA is the difference between NOPAT and cost of capital.

$$
E V A=N O P A T-c * I
$$

\section{NOPAT}

It is the Operating profit before interest but after payment of taxes. The number of adjustments to be 
made to accounting figures will vary from country to country depending upon the GAAP prevailing in the country. But four generally applied adjustments, equity equivalents, are 1. Amortization of Goodwill; 2.Amortization of R\&D cost; 3.LIFO reserve; 4.Adjustment for deferred tax reserves.

$$
\text { NOPAT }=\text { PBIT }(N N R T) \quad(1-T)
$$

Where PBIT (NNRT) is profit before interest and taxes (net of non-recurring transactions)

$$
\text { PBIT }(\text { NNRT })=\text { PAT + taxprovisions + }
$$

interestexpenses + leaserent- extraordinaryincome + extraordinaryexpenses

$\mathrm{T}$ is the effective tax rate.

\section{Capital Employed}

Capital Employed can be calculated using the following equation

\section{CE $=$ CurrentAssets + NetFixedAssets - NoninterestBearingCurrentLiabilities $=$ IntersestBearingDebt + NetWorthLessanyNonOperatingAssets}

Capital Employed for EVA calculations shall be adjusted for four equity equivalents mentioned above. The capital employed can also be calculated using the below formula

InvestedCapital $=$ NetWort $h+$ TotalBorrowing With:

\section{- NetWorth = ShareCapital + ReserveandSurplus - RevaluationReserve-AccumulatedLosses- MiscellaneousExpenditure \\ - TotalBorrowings = LongTermInterestBearingDebt + ShortTermInterestBearingDebt}

To calculate EVA, we always use beginning of the year capital employed. Also, it is advisable to use the book value of capital employed.

\section{LITERATURE REVIEW}

Studying M\&A performance has been the focus of multiple disciplines including, but not limited to, Corporate Finance and Strategy. Multiple approaches have been used to assess the performance of different mergers and acquisitions. Zollo and Singh (2004) asserted that amount of heterogeneity, both in defining performance and approaches to measuring it has been tremendous. Zollo\& Meier identified close to twelve different approaches used by researchers to assess the performance of M\&As between 1970 and 2006. These approaches vary along different parameters.

These studies raise the question whether the M\&A activity on an average has benefited the shareholders of acquiring companies? Several studies have shown that the Target firms' share holder benefit the maximum from merger gains. Unlike other capital investment decisions acquisitions create immediate impact on shareholders' value. The objective of the paper is to develop a methodology to forecast and evaluate operating performance post-acquisition.

One of the fundamental problem in developing a method to assess the actual synergies has been the absence of basis against which the post-merger operating performance shall be compared. Only when the improvement in performance of combined entity is more than the acquisition premium the investment is justified. Till date most of the studies have used return on stocks or accounting returns as the performance indicators. Further studies linking the short-term market reaction and long term stock performance indicated that market reaction gives an unbiased measure of long rum impact on value of acquiring firm.

Other studies have focused on return matrices such as return on sales, return on assets and compared them before and after the acquisition assuming past performance as the benchmark for future performance.

Shareholders have the options of investing in the stock of two independent entities themselves and therefore any acquisition must be justified by improved performance over and above what in already reflected in the market prices of two stocks. Therefore, any performance benchmark shall be able 
to exclude performance reflected in the stock prices of independent firms. Therefore, rather than the past performance the performance expected by firm (as reflected in stock market prices) shall be the basis for bench marking. To do that a valuation model linking current market value to performance parameters was employed. A method that separates known component of market values from expected one.

\section{OBJECTIVE}

The objective of the paper is to demonstrate value based approach for evaluating post-merger performance. Enterprise Value Added (EVA) as outlined by Stewart in 1980 has been chosen as the value based measure. EVA methodology was employed as a tool to evaluate the post-merger performance of the combined entity Hindalco in the paper. The objective is to found whether the combined entity could produce expected performance. The five years post-merger analysis of combined entity's (Hindalco) is carried out using economic value added (EVA). The other objective is also to calculate the actual EVA and compare it with the expected EVA improvements in the combined entity, in order to know that whether the target company being over-valued during acquisition process by acquiring company, Hindalco. A Case of Hindalco Industries Ltd. and Novelis Inc is chosen for the paper.

\section{Company Overview of the Acquirer, the Target and the Deal}

\section{The Acquirer: Hindalco Industries Ltd.}

Hindalco Industries Ltd. is an aluminum manufacturing giant established in year 1958 and headquartered in Mumbai, Maharashtra. It is a flagship firm of Aditya Birla Group in the metal business. It's production began in year 1962 from Renukoot district of Uttar Pradesh producing aluminum metal and alumina. Today, it is well placed in the market commanding a market capitalization of more than USD 3.2 billion, generating average annual revenue of more than USD 15 billion and -employing approximately 20,000 people. It represents two strategic arms of the company managing two strategic business of aluminum and copper and is regarded as one of the largest aluminum rolling companies in the world. The company is listed in national and international bourses of Luxembourg Stock exchange, BSE and NSE, and trades in London Metal Exchange. Further, it boasts of international clientele, exporting its products to nearly 30 countries of North America, Asia and Western Europe. The company is regarded as the most cost-efficient aluminum producer in the world owing to its integrated operations and operating efficiency. Prior to the acquisition deal, Hindalco had posted consistently increasing PAT along with the fact that its actual production exceeded its installed capacity.

\section{The Target: Novelis}

Novelis Inc. was a substantial global player in the industrial aluminum sector, headquartered in Atlanta, Georgia, USA. It was hailed as the global leader of beverage can recycling and one of chief producer of rolled aluminum producing approximately $19 \%$ of global production for flatrolled aluminium products. It's recycling capacity stood at recycling of 35 billion beverage can annually. It used to boast of known names of the companies of the world as its client namely, CocaCola, Kodak, Anheuser-Busch, Ford, Tetra Pak, Agfa -Gevaert, Crown Cork \& Seal, ThyssenKrupp, General Motors, etc. Its strength lied not only in its clientele base or diversified product portfolio but also in its geographical reach having the presence in four continents of the world. Interestingly, Novelis was essentially the part of Canadian Aluminium manufacturer Alcan Inc and was separated to form an individual entity in year 2005. Subsequently, in year 2007 it was acquired by Hindalco for an estimated cost of USD 6 billion making Hindalco to be the global heavyweight amongst integrated aluminium players. Its shares also traded on varied bourses of New York Stock Exchange (NYSE) and 
Toronto Stock Exchange (TSE).

\section{The Deal}

The root cause of the acquisition of a global heavyweight, NovelisInc in year 2005 the substantial loss incurred by it year 2006. With global presence, shock of the sudden increase in world's Aluminum prices was also of large scale. Between September 302005 and 2006, the world's Aluminum prices witnessed an appreciation of $39 \%$ in its prices which it was not able to pass on to its customers globally owing to their earlier contract and commitments. Consequently, a net loss of USD 275 million in year 2006 against the net income of USD 90 million in year 2005 was incurred by it.

Correspondingly, on another front Hindalco Industies Ltd was reflecting a fortified and impressive position posting year-on-year profits. Its PAT increased from Rs. 686 crore in year 2002 to Rs. 2564 crore in year 2007.

Hence, the two contrasting positions of two competitors offered an attractive option to Hindalco Industries Ltd to make a global imprint by acquiring Novelis Inc. in year 2007. The acquisition on Novelis by Hindalco was announced on February11, 2007, while actual acquisition was made on May 15, 2007 post approval from Ontario Supreme Court of Justice, Canada. Hindalco acquired all 75,415,536 outstanding common shares of Novelis at a price of USD 44.93 per share. The deal terminated all outstanding stock options and other equity incentives in exchange for the cash payments. Also, Novelis'debt of USD 2.8 billion was acquired by Hindalco at a net cost of USD 6.2 billion. The acquisition of Novelis was actually made by the acquisition subsidiary of Hindalco, namely AV Metals according to the agreement entered on February 10, 2007. Subsequent to the acquisition, immediately, the common shares of Novelsi were transferred from AV Metals (Hindalco's subsidiary) to its wholly-owned subsidiary AV Aluminum Inc.

At the domestic forefront of Hindalco Industries Ltd., the deal did not appeared to go well down with the investors at the bourses. The stock prices of Hindalco Industries Ltd. exhibited a sharp plunge. For instance, the share price of Hindalce a day before the announcement of deal was quoted at Rs.160 per share. But the same share price was found at Rs.125 per share when noted 10 days after the announcement of the deal. Probably the premium of Rs. 2300 crores paid by Hindalco to Novelis over and above its estimated market value of Rs. 22100 crore was perceived by the market to be exorbitantly high. The reaction was in accordance with the perception of the market as noted from Table 1.

The details of the deal are presented in the Table 1.

Table 1

\begin{tabular}{|l|l|}
\hline Date of Announcement & February 11, 2007 \\
\hline Stock Price of Hindalco the day before & INR 160 per share \\
\hline Stock Price of Hindalco after 10 days & INR 125 per share \\
\hline Market Value of Novelis Inc. & INR 22100 Crore \\
\hline Premium Paid over Market Value & INR 2300 Crore \\
\hline Total Value of the Deal & INR 24400 Crore \\
\hline
\end{tabular}

Source: Bloomberg data base

\section{METHODOLOGY}

Present study uses EVA as a measure of performance assessment post-merger. The model that is used to evaluate performance draws heavily from the work of Miller and Modigilani, Mark L. Sirower and Stephen F. O'Byrne (1998). Furthermore, data required to carry out the successful EVA 
analysis of deal, has been collected from multiple sources including NSE, companies annual report, US Security Commission and Bloomberg.

\section{EVA Based Performance Evaluation Model}

Miller and Modigilani in their paper "Dividend Policy, Growth and Valuations of Shares" demonstrate that the market value is the PV of future Free Cash Flows (FCF) discounted at WACC. However, FCF does not provide a reliable means of operating performance because it subtracts the investment from operating profit after tax in the year of investment itself rather than spreading the investment over its entire useful life. This shortcoming can be eliminated by using the concept of EVA (Economic Value Added) which is calculated by subtracting $\mathrm{c}^{*} \mathrm{I}$ from NOPAT.

$$
E V A_{o}=N O P A T-c^{*} I_{-1}
$$

Where, NOPAT is the Net Operating Profit after Tax, $I_{-1}$ is the total invested capital at the beginning of the year and $c$ is the weighted average cost of capital.

The following relation between market value and EVA than can be established

\section{MV = Invested Capital + PV of Future EVA}

The above equation is important because of its division of Market value into known and expected component.

$$
M V_{0}=C a p_{0}+\frac{E V A_{0}}{c}+((1+c) c) * \sum_{t=1}^{\infty} \frac{\Delta E V A_{t}}{(1+c)^{t}}
$$

Where, $\mathrm{MV}_{0}$ is the market value at the end of year 0 , $\mathrm{Cap}_{0}$ is the book capital at the end of year 0 .

The first two terms of the equation give the Current Operations Value (COV) while the last term gives the Future Growth Value (FGV). The EVA improvement $(\Delta)$ required to ensure a rate of return equal to cost of capital on FGV will be given by the following formula

$$
\Delta E V A_{1}+\frac{\Delta E V A_{1}}{c}+\Delta F G V=c * F G V_{0}
$$

Assuming zero changes in FGV the above equation can be rewritten as follows

$$
\Delta E V A_{1}=\left(\frac{c^{2}}{1+c}\right) * F G V_{0}
$$

The present study seeks to study the post-merger performance of a corporate entity. Since the established objective of a firm is to create wealth for the stockholders, Value based parameter i.e. EVA has been chosen to measure the performance. To incorporate the complexities associated with a cross border M\&A deal, have the adequate post-merger data to carry out the analysis and ensure that no further acquisition was undertaken by acquiring firm in the period of evaluation merger deal between Hindalco Industries Ltd. and Novelis Inc. carried out in the year $2007,11^{\text {th }}$ of February has been chosen.

The following steps were followed to estimate the post-merger performance:

Step 1. For both the acquirer and target entities, future growth value and the expectational component of market value needs to be computed which would also include the acquisition premium.

Step 2.Preparation of Performance Benchmark: Two parameters namely, EVA improvement where costof-capital return represents the perpetuity value, and cost of capital return on FGV are computed in this step.

Step 3.EVA improvements is computed in this step.

Step 4. Excess EVA improvement is subsequently estimated

Step 5. Present value of excess of EVA improvement needs to be computed in this step.

\section{ANALYSES AND INTERPRETATION}

Table 2 below provides the analyses of Novelies (target) Inc. Table 3 provides the analyses of Hindalco Inc (The acquirer ). Table 4 gives the details of analyses of Hindalco Industries Ltd., as a combined entity. 
Novelis Inc.

Table 2: Financial Details of Novelis Inc. for year 2006

\begin{tabular}{|c|c|}
\hline Pre-acquisition Status of Novelis & Figures in Rs. \\
\hline PAT & $-1210^{*}$ \\
\hline Interest & $972.4^{*}$ \\
\hline NOPAT & $-237.6^{*}$ \\
\hline Premium Paid & $2301.2^{* *}$ \\
\hline Beginning Capital & $10714^{*}$ \\
\hline Rf & $0.0476^{* *}$ \\
\hline $\mathrm{Rm}$ & $0.06^{* *}$ \\
\hline Beta & $1.6^{* *}$ \\
\hline Ke & $0.1436^{\star *}$ \\
\hline $\mathrm{Kd}($ after tax $)$ & $0.0565^{* *}$ \\
\hline Leverage & $1.2249 * *$ \\
\hline We & $0.4494^{\star *}$ \\
\hline Wd & $0.5505^{* *}$ \\
\hline WACC & $0.0957^{* *}$ \\
\hline EVA & -1262.4872 \\
\hline $\mathrm{COV}$ & -2483.8307 \\
\hline Book Value of Debt & $10560^{* *}$ \\
\hline MV & $24098.8^{* *}$ \\
\hline FGV & 26582.6307 \\
\hline Return & 2542.8597 \\
\hline$\Delta$ EVA expected & 222.0095 \\
\hline
\end{tabular}

- *Company Annual Report

- ..**Bloomberg data base

The financial results of Novelis, for the year ending 2006 shows that Novelis had a negative NOPAT. Based on the leverage, the WACC for Novelis came out to be $10 \%$ as shown in table 2 . Subtracting cost of beginning capital from NOPAT gives a negative EVA. This ultimately resulted into a negative COV of Rs. 2483 Crores and hence higher FGV of Rs. 2658
Crores. The multiple of FGV and WACC produced the returns of Rs. 2543 crores for the firm. Subsequently, the actual EVA improvements for the Novelis came out to be less, by an amount close to Rs. 1040 crores. than EVA improvement expected considering the premium paid. 
Hindalco Industries Ltd.

Table 3: Financial Details of Hindalco Inc. for year 2006

\begin{tabular}{|c|c|}
\hline Pre-acquisition Status of Hindalco Industries Ltd. & Figures in Rs. \\
\hline PAT & $2703^{*}$ \\
\hline Interest & $488.5^{*}$ \\
\hline NOPAT & $3191.5^{*}$ \\
\hline Net Assets & $19031^{*}$ \\
\hline Current Assets & $8668^{*}$ \\
\hline Non-Interest Bearing Liabilities & $4411^{*}$ \\
\hline Beginning Capital & $23288^{*}$ \\
\hline $\mathrm{K}_{\mathrm{e}}$ & $0.1684^{* *}$ \\
\hline $\mathrm{K}_{\mathrm{d}}($ after tax $)$ & $0.047775957^{* *}$ \\
\hline Leverage & $0.658656472^{* *}$ \\
\hline $\mathrm{W}_{\mathrm{e}}$ & $0.602897596^{* *}$ \\
\hline $\mathrm{W}_{\mathrm{d}}$ & $0.397102404^{* *}$ \\
\hline WACC & $0.120499903^{* *}$ \\
\hline EVA & 385.2982644 \\
\hline $\mathrm{COV}$ & 26485.49855 \\
\hline Number of shares & 1227190692 \\
\hline Share Price & 158 \\
\hline Market Cap & $19389.61293^{* *}$ \\
\hline Book Value of Debt & $8442^{* *}$ \\
\hline MV & $27831.61293^{* *}$ \\
\hline FGV & 1346.114384 \\
\hline Return & 162.2066524 \\
\hline$\Delta$ EVA expected & 17.44389784 \\
\hline
\end{tabular}

- *Company Annual Report

-..**Bloomberg data base

The financial results of Hindalco, for the year ending 2006 shows that Hindalco had a positive NOPAT of Rs.3191 crores. Based on the leverage, the WACC for Hinddalco came out to be $12 \%$ as shown in table 3 . Subtracting cost of beginning capital from NOPAT gives a positive EVA. This ultimately resulted into a positive COV of Rs. 26485Crores and hence lower FGV of Rs. 1346Crores. The multiple of FGV and WACC produced the returns of Rs. 162crores for Hindalco. Ltd. The change in expected EVA for Hindalco came out to be amount close to Rs.17 crore. 


\section{Hindalco Industries Ltd.: Consolidated}

Table 4: Financial Details of Consolidated Hindalco Industries Ltd. after the Acquisitionfor year 2007 and forecasted years (five in all)

\begin{tabular}{|c|c|c|c|c|c|c|}
\hline \multicolumn{7}{|c|}{ Combined Entity } \\
\hline & Proforma Year & $\begin{array}{c}\text { Forecasted Year } \\
1\end{array}$ & $\begin{array}{c}\text { Forecasted Year } \\
2\end{array}$ & $\begin{array}{c}\text { Forecasted Year } \\
3\end{array}$ & $\begin{array}{c}\text { Forecasted Year } \\
4\end{array}$ & $\begin{array}{c}\text { Forecasted Year } \\
5\end{array}$ \\
\hline PAT & & 2623 & 348 & 4351 & 2879 & 3559 \\
\hline Interest & & 2209 & 1565 & 1439 & 1839 & 1758 \\
\hline NOPAT & 2953.9 & 4832 & 1913 & 5790 & 4718 & 5317 \\
\hline Net Assets & & & 38104 & 34765 & 34801 & 41657 \\
\hline Current Assets & & & 21474 & 19270 & 23188 & 32424 \\
\hline $\begin{array}{l}\text { Non Interest } \\
\text { Bearing } \\
\text { Liabilities }\end{array}$ & & & 17203 & 16260 & 18017 & 15660 \\
\hline Beginning Capital & 49688 & 49688 & 42375 & 37775 & 39972 & 58421 \\
\hline WACC & 0.107301386 & 0.11 & 0.11 & 0.11 & 0.11 & 0.11 \\
\hline EVA & -2377.691243 & -633.68 & -2748.25 & 1634.75 & 321.08 & -1109.31 \\
\hline $\mathrm{COV}$ & 27529.00148 & 43927.27 & 17390.90909 & 52636.36364 & 42890.90909 & 48336.36 \\
\hline Number of shares & & $1.7 \mathrm{E}+09$ & 1914008691 & 1914944163 & 1915088557 & $1.91 \mathrm{E}+09$ \\
\hline Share Price & & 180 & 44 & 162 & 245 & 118 \\
\hline Market Cap & & 30614.71 & 8421.63824 & 31022.09544 & 46919.66965 & 22592.08 \\
\hline Book Value of Debt & & 32353 & 28309 & 23999 & 29365 & 40858 \\
\hline MV & 54231.61293 & 62967.71 & 36730.63824 & 55021.09544 & 76284.66965 & 63450.08 \\
\hline FGV & 26702.61146 & 19040.43 & 19339.72915 & 2384.731804 & 33393.76056 & 15113.72 \\
\hline Return & 2865.227206 & 2094.4 & 2127.4 & 262.3 & 3673.3 & 1662.5 \\
\hline ? EVA expected & 277.6505593 & 277.7 & 277.7 & 277.7 & 277.7 & 277.7 \\
\hline ? EVA Actual & & 207.6 & 210.8 & 26.0 & 364.0 & 164.8 \\
\hline $\begin{array}{l}\text { Excess } \\
\text { Improvemen } \\
t\end{array}$ & & -70.1 & -66.8 & -251.7 & 86.4 & -112.9 \\
\hline $\begin{array}{l}\text { PV of Excess } \\
\text { Improvemen } \\
\text { ts }\end{array}$ & & -63.146 & -54.24034501 & -184.0074369 & 56.89596079 & -66.9988 \\
\hline Cumulative PV & -311.4966682 & & & & & \\
\hline $\begin{array}{l}\text { Capitalized } \\
\text { Cumulative } \\
\text { PV }\end{array}$ & -3214.503621 & & & & & \\
\hline Market Reaction & -3067.97673 & & & & & \\
\hline
\end{tabular}

Observing the data of the consolidated firm, Hindalco Industries Ltd. in the post-acquisition space, it was observed that NOPAT was positive for the all the years. However, EVA turned out to be negative for three out of five years reflecting higher beginning capital than the NOPAT earned by the consolidated entity. However, Current Operations
Value (COV) was found to be sufficiently high ranging from approximately 44000 crore estimated in year 1 to 48000 crore estimated in year 5 . Additionally, owing to higher market value than $\mathrm{COV}$, the future growth value turned out to be fluctuating generally around Rs.19000 crores. The return estimated by the product of FGV and WACC 
emerged at Rs. 1900 crores approximately. Subsequently, the improvement in EVA emerged to be Rs.70 crores for the forecasted year 1 and Rs.113 crore for the forecasted year 5 .

In essence, results show negative EVA up to two years after acquisition despite earning positive NOPAT. This indicates that the company failed to recover its cost of Capital in those years. The EVA approach clearly shows that in the aftermath of acquisition, four out of five years the actual EVA improvements fell short of the expected EVA improvements. This in present value terms culminated into the deal being overvalued to the tune of more than Rs.3200 Crore. The market in the aftermath of the merger reacted negatively and considered the deal overvalued to the tune of Rs.3068 Crore. The comparison of two results shows that market reaction is an adequate measure of the post-merger performance expectation for the firm.

\section{CONCLUSION}

It has been illustrated that numerous approaches are available to assess the post-merger performance of the combined entities. However, EVA, a value based measure due to its superior methodology was employed as a tool to evaluate the post-merger performance of the new entity. The value obtained from the analysis found that the combined entity couldn't produce expected performance. The five years post-merger analysis of combined entity's performance revealed four years of negative economic value (EVA). This underlined that the actual EVA couldn't keep up with the expected EVA improvements in the combined entity, thereby validating the fears of the target company being over-valued during acquisition process by acquiring company, Hindalco. Most importantly, results also revealed negative capitalized cumulative value in the post-merger analysis. This indicated that the deal was an over-priced one where the acquirer ended up paying excess premium to the target company, significantly over and above the market value which did not paid them off.

\section{REFERENCES}

1) Betas by Sector (US). (2017, January). Retrieved 2017, from Stern, New York University: http:// pages.stern.nyu.edu/ adamodar/New_ Home_Page/datafile/Betas.html

2) Allen, F., Bhattacharya, S., Rajan, R., \& Schoar, A. (2008, Fall). The contributions of Stewart Myers to the theory and practice of corporate finance. Journal of Applied Corporate Finance, 20(4).

3) Amendment to Form S-4, Registratiion statement under The Securities Act of 1993. (n.d.). Retrieved 2017, from United States Securities and Exchange Commission: https:/ / www.sec.gov/Archives/edgar/data/13 04280/000095012309051624/g20430a1sv4za.htm \#105

4) Cording, M., Christmann, P., \& Weigelt, C. (2010, March). Measuring theoretically complex constructs: The case of acquisition performance, strategic organization. Strategic Organization, 8(1), 11-41.

5) Dickerson, A., Gibson, H., \& Tsakalotos, E. (1997, July 3). The impact of acquisitions on company performance: Evidence from a large panel of UK firms. Oxford Economic Papers, 49(3), 344-361.

6) Miscellaneous Links. (n.d.). Retrieved 2017, from Money Control: http://www.moneycontrol.com

7) Oghuvwu\&Omoye. (2016). Mergers, acquisitions and corporate performance: The balanced scorecard approach. Accounting and Finance Research, 5(4), 63-75.

8) Sarkar, B. (2013, April 9). Estimating the cost of capital of CNX Nifty. Retrieved January 2017, from NSE India: https://www.nseindia.com/research/content/ RP_9_Apr2013.pdf

9) Sirower, M., \& O'Byrne, S. (1998, Summer). The measurement of post-acquisition performance: Toward a value-based benchmarking methodology. Journal of Applied Corporate Finance, 11(2), 107-121.

10) Wang, D., \& Moini, H. (2012). Performance Assessment of Mergers and Acquisitions: 
Evidence from Denmark. Retrieved 2017, from E-Leader Berlin: https://www.gcasa.com/conferences/berlin/papers/Wang.pdf
11) Zenner, M., Hill, S., \& Clark, J. M. (2008). The most important number in Finance; The quest for the market risk premium. J P Morgan. 